\title{
The State of Art Education Students' Project Works: the Case of UEW
}

\author{
Esseku, J. F.* \\ Department of Graphic Design School of Creative Arts University of Education, Winneba - Ghana \\ *Corresponding Author: Esseku, J. F., Department of Graphic Design School of Creative Arts \\ University of Education, Winneba - Ghana
}

\begin{abstract}
This paper, grounded in the mixed-method design and descriptive analysis, is aimed to draw attentions toward the importance of storing, preserving and archiving students' art works to aid teaching and learning of visual arts and howstudents' project works produced by Art Education students at the University of Education were documented, stored, preserve or archived after assessment. The researcher looked at seven units within the Department of Art Education of the University of Education, Winneba and how best they have documented, stored, preserved, or archived students' project works since the inception of the Department or any work done in this regard. The seven units the researcher looked at were the basketry, ceramics, jewellery, leatherwork, painting, sculpture and textiles. It turned out that no attempt has been done in storing, archiving or documenting any sort; apart from disposing of quality works of students, giving them away for free and leaving them at the mercy of the weather to be destroyed. The researcher interacted with seven senior members within seven units of the Department Art Education through the purposive sampling technique to secure data for this paper. These seven senior members were Purposively selected to obtain data for this paper using the unstructured interview and observational methods. Primary data obtained were analysed descriptively and narratively. The only standard forty-seatercapacity lecture room sized convertedinto gallery of the Department of Art Education is not able to hold all the selected best final year students' project works. The gallery is not in the best condition to hold art works as dust continue to destroy the works as well as the gallery has no curator but left in the care of office assistants. The researcher recommends that the Department of Art Education contract web designers to design a databaseto host still images and $360^{\circ}$ moving images of these art works to start with in solving this challenge of the Department.
\end{abstract}

Key terms: Art, archive, education, project, Winneba

\section{INTRODUCTION}

Final year art education students of the Department of Art Education at the University of Education, Winneba (UEW) as part of their study for the award of various certification take practical courses within each semester throughout their study and they produce a minimum of sixteen or more art (project) works depending on the programme the student offers. Art unlike other theoretical inclined programmes, require extensive time and studio to come out with compelling works (Nortey \& Bodjawah, 2014). The Department of Art Education of the University of Education, Winneba is one of the oldest departments of the University when the department of the Teacher Training section of the Art and Crafts Specialist Course(ACSC) was transferred from Kumasi to Winneba in 1958 (Edusei, 2004; I.U.B., 2019; Seid'ou, 2020).This was part of the then Specialist Teacher Training College and the only department founded to train specialist art teachers by going through a vigorous and stringent training in art education until the 1973-1974 academic year when a three-year specialist course in Art was established in a number of basic Teacher Training Colleges (Edusei as cited by Kassah \& Kemevor, 2016). The sole aim of the government was to deepen the study of art in Ghanaian schools and the establishment of a special training college was in the right direction to award a certificate and later diploma certificate. The Specialist Training College established in Winneba offered three flagship programmes viz; Home Economics Education, Art Education and Physical Education (PE) that supplied art, home economics and physical education teachers to Ghanaian schools. Teachers from the Specialist Training College were highly sought after by heads of secondary schools then and the headmasters of secondary schools who sought after teachers from (STC) enticed graduates who studied these three programmes within their means. The Specialist 
Training College in Winneba was part of diploma awarding institutions that was put together in September 1992 under PNDC Law 322 to form the then University College of Education of Winneba (UCEW), (UEW, November, 2018).

The study of art in Ghana dates back to 1909 when visual art as a subject was included on the school time-table as "hand and eye" to change the mere bookishness of the school course, (Edusei, 2004). Before visual art was introduced to the school time-table in 1909, it had first been introduced in the then Gold Coast, now Ghana in 1908 (Foster as cited in Edusei, 2004). Visual art referred to as "hand and eye" involved the student copying various shapes and lines to enable develop the student's coordination (Edusei, 2004). Edusei (2004) elaborated the history of art by laying it bare how the missionaries who started education in the castle referred to art as 'paganistic' culture which the missionaries abhorred until 1919. It is obviously clear that visual art students produced art works that pertained to the indigenous Ghanaian culture, especially what the missionary teachers termed 'primitive' and 'fetishistic' relating to the Ghanaian indigenous religion (Edusei, 2004), was clear that the missionary castle school teachers did not make any attempt to preserve works produced by their students in this direction. Obviously, this attitude of the missionary castle school teachers contributed to the lack of the Ghanaian visual art schools to inculcate the habit of preserving, storing or archiving art works to date at every level of the Ghanaian school offering art especially at the tertiary levels.

The focus of this paper is to look at the state of students' art (project) works at the Department of Art Education of the University of Education, Winneba; how these works are stored, preserved or archived. The importance of storage, preservation and archiving of students' art works have seriously been neglected over a long period of time through all the Ghanaian educational levels as it stands.Jadzińska (2013) opines that to think of culture, art must be taken care of. Not even the 2019 Creative Arts curriculum for Primary Schools included in its subject aims the preservation, storage and archiving or creative art projects (NaCCA, Ministry of Education, 2019). Ohene-Adu as cited in Sei'dou, 2015 p.15 on a similar mission hinted that "the task would seem to be even more pertinent today when the charge of apathy towards the University's artefacts appears to be tenable", but which the writer suggested documentation and attributions to works on the $\mathrm{KNUST}^{1}$ campus would find important resource.

The Department of Art Education at the University of Education, Winneba has existed from the onset of the establishment of the then University College of Education of Winneba in 1992 but cannot boast of a curator when KNUST has curators who spearhead regular exhibitions (Diallo, 2017). The Art Education Department run a diploma and bachelor programmes and; postgraduate programmes. Any student who study at the undergraduate level is mandated to choose elective courses in both 2Dimensional and 3-Dimensional areas of visual art including other mandated general art courses. Depending on the programme one opts to study, a student goes through four semesters for a Diploma programme and eight semesters for a degree programme (Duku \& Osei-Poku, 2012). During the course of study, students produce a minimum of either eight to fifteen projects.

The establishment of Achimota school influenced the strong introduction of African art and its principles influenced and shaped the school's programme. Kwame Nkrumah; Ghana's first Prime Minister and President (Elias, 1957) contributed greatly to the development of the creative industry in Ghanaincluding the commissioning works of leading artists like Kofi Antubam, Saka Acquaye, Dr Oku Ampofo, Philip Gbeho (who composed the Ghana national anthem), and Ephraim Amu (who composed the popular anthem "Yen ara ya Asase ni") in the Akan language. From the narrative above, much effort was made to establish art among the Ghanaian fabric of life. There have been major educational reforms in Ghana which have not left out visual art in the educational curriculum to serve its purpose in the development of the nation. The direct effect of theseeducational reforms has but little impact to show when one visitsall government owned Ghanaian schools which offer visual arts in Ghana today to show off. National educational systems change in response to the demands of the nation (Mereku, 2020). It is evident from the above narration that all visual art forms from time memorial allowed the practitioner produce art works which most commissioned sculptural works are evident on the Ghanaian streets to see and maintained for example the Kwame Nkrumah Mausoleum (Savage, 2009).

\footnotetext{
${ }^{1}$ Kwame Nkrumah University of Science and Technology, Kumasi-Ghana 
The 1987 Educational reform programme saw visual art integrated into the school curriculum (Essel et al., 2017). Everyone is born an artist; as individuals have an artistic innate in them especially when we go shopping or faced with making a choice of daily items around us. Everyone needs art; as (Martin, 2014) identified several benefits of art in education to children. To grow the artistic innate in students, the challenge is how to nurture and sustain such artist traits (Essel,Nunoo\& Ahiaklo-Kuz, 2017). The ability to store, document, preserve and archive art works should be seriously looked at. Art works typical of Ghanaians depict the Ghanaian culture and for that matter, artist and stakeholders in art in Ghana must endeavour to store, preserve, document and archive art works in any form.Ross (2004) stated that these art forms are part of the visual vernacular that serve to identify Ghana and Africa in general. Ross (2004) advanced her point by indicating the fact that, in Ghana, visual references to indigenous arts are everywhere, in architecture, corporate advertising, textiles, entertainment, artifacts and myriad forms of popular visual culture, much of which are produced for consumption. Obviously, there is the need to preserve, document and archive these works of art to make it available for teaching and learning within Ghanaian schools today. Much work has not been done in protecting Ghana's unique cultural heritage (Ross, 2004). This development has not changed since Ross made this observation. Though the government makes enormous effort in investing in education in Ghana today, the desired investments towards art education as compared to the investment the government makes towards Information and Communication Technology (ICT) does not commensurate that of art education; even though conscious efforts have been made in the direction of expanding internet access and digital skills to Ghanaian schools by the government of Ghana the problems persist (Endert, 2018). Theeffort of the government to invest in ICT and internet access lend itself to the effort tertiary institutions in Ghanaare making considering the portion of their budget they invest into ICT and internet access especially in the wake of COVID-19 but this effort is not extended at investing in art education. The creative arts continue to receive meagre logistic and financial support (Artwatch Ghana, 2017). Brobbey (2015) opined that creative art education is the ideal way to develop creative thinking in learners to be able to withstand the competitive challenges of the 21 st century.

The call to integrate information and communication technology in education is the trump card of the 21st education which education stakeholders and policymakers across the globe continue to call for (Agyemang et al., 2019). Considering the strategic introduction of GARNET (Ghana Research and Academic Network, which cater for universities, research institutions and high schools (Quaynor et al., 2020) this system has not made room in the storage, preserving and archiving students' art works though some universities in Ghana are signed onto the DSpace ${ }^{2}$ software to create repository to host students' theses. Considering the technology skills acquired by Ghanaian students today and the tools available, the issue of preserving, storing and archiving art works within tertiary institutions in Ghana should be looked at.The Smithsonian libraries hold a collection of digital modern African Art materials on its National Museum of African Art Branch Library repository as a work-in-progress (Stanley, 2020). The Smithsonian Libraries section on modern African art holds among other resources image gallery, art and artists files, audio and video files as well as exhibitions.

Researchers and students often refer to repository for materials to support their academic works; so, the unavailability of archived, preserved or stored art works in any form is a bad practice at the Department of Art Education and among Ghanaian government visual art schools goes a long way in discouraging visual arts students today. Visual arts projects at the Department of Art Education are invaluable asset to visual arts students as well as practicing visual artists. The importance of storage, documenting, preserving and archiving visual arts students' project are unavailablethough these project works are a wealth of source of knowledge that aid in the teaching and learning of Art Education at the Department of Art Education. There have been new and innovative ongoing developments at the College of Art at KNUST to help shape the contemporary Ghanaian art scene while the case of the Art Education Department in $\mathrm{UEW}^{3}$ is in comma waiting for its resurrection but without any form of resuscitating itwhen the Ghanaian art scene requires a stronger infrastructure (Diallo, 2015). The Department of Art Education at the University of Education, Winneba obviously also require the "silence revolution" (I.U.B., 2019).

\footnotetext{
${ }^{2}$ It is an open source repository software package typically used for creating open access repositories for scholarly and/or published digital content.

${ }^{3}$ University of Education, Winneba
} 
Kassah \& Kemevor (2016) chronicled the challenges of visual arts education in Ghanaian colleges but the issue of the preservation, storing and archiving art works of Colleges of Education students was not touched on neither did they perceive this issue as a challenge that affect the teaching and learning of visual arts in Ghana. This is a major gap in the promotion of art education and the production of art works by students in Ghanaian schools to aid the teaching and learning of visual artsin Ghana as art education policy makers have failed to give the storage, preservation and archiving, the requisite attention so as to encourage art students to invest in their project works. Teachers have often dwelled on students' previous knowledge and teaching and learning materials in lesson delivery which the availability of students' project will serve in this case but are left at the peril of the weather. To buttress this challenge in visual art schools, Mensah (2009 p.16) stated that where studio conditions are good, "only few works are kept there leaving the rest to the mercy of the weather. Students seeing these are often discouraged from working hard to come out with quality works".

\section{Methodology}

This paper adopted the mixed method which offered the researcher a legitimate use of multiple approaches in providing answers to the demands of the paper. The qualitative and quantitative approaches and the descriptive analysis concurrently merge with the purposive sampling technique formed one interpretation of the basis of the data that influenced selecting seven units of the Department of Art Education as samples for the study. The seven units sampled were the basketry, ceramics, jewellery, leatherwork, painting, sculpture and textiles units. The purposive sampling technique was opted because initial studies taken show these unitshave large number of art works produced by students studying art education at the Department of Art Education. These works of art produced by students are scattered all over the department and sprawled out of the correspondingunits. The Department of Art Education has more than seven units out of which seven was selected for this study. The researcher interacted with seven senior members and thirty-four (34)course representatives comprising general representatives of each year group (100-400) across the seven units which came up to twenty-eight. In addition to these twenty-eight course representatives studying for first degree (levels one hundred to level four hundred), four diploma one and two (levels one hundred and level two hundred) course representatives for Textiles and Leatherworks were also interviewed which are also within the seven units of the Art Education Department to secure data for this paper. These seven senior members from these units have a range of twenty-five to a minimum of seven years teaching experience at the units in question. These seven senior members were purposively selected to obtain data for this paper using the unstructured interview and observational methods.

As of the time of collecting data for this paper, the Art Education Department run only two courses at the diploma level and these diploma programmesare for a duration of two years. The researcher worked with the course representatives because they worked closely with the various lecturers and their course mates among other duties including accepting and presenting assignments and projects of their course mates to their lecturers and return same when it has been assessed.

The duties of the course representatives were to also locate avenue for exhibition of their projects works for assessment by their various lecturers. Considering their invaluable role the course representatives play, they were the best choice for the researcher to obtain part of the primary data for this paper. The choice of two course representatives for each course in every year comprising a male and a female student was a perfect balanced. Primary data obtained were analysed descriptively and narratively. Four units viz; basketry, jewellery, painting and textiles out of the seven units selected for this study had students works over a period of five years while the other three had only current academic year students'works. These three units have serious space issue. It was evident how students' project works were stored, preserved or archived and made available.

\section{RESUlTS AND DisCUSSIONS}

Technology today defies the traditional structures for exhibiting, collecting and preserving art (Noordegraaf et al., 2013).It appears much effort is being turned towards the collection, analysis, documentation, preservation and restoration of media art in the European universities which are among the leaders of teaching media art programmes but the case of art which most Ghanaian universities continue to teach have not been attended to in terms of its storage, preservation and archiving. Students' project works are rather disposed of at the Department of Art Education semester 
by semester because the very studios and lecture rooms are required for teaching every semester. Students are forced to clear and discharge these projects works initially within a close proximity of either the lecture rooms or studios in which the said students used. The Department of Art Education in the era of University College of Education of Winneba had less than sixty-five students for their various diploma courses within an academic year (Opoku-Mensah, 2020; Acquah, 2020; Gyimah, 2020; Ockumpah-Bortei, 2020). In 2018, the Department of Art Education in the era of the University of Education had a total student population of nine hundred and seventy-four (University of Education, Winneba, 2018). From these data, the intake of students in the Department of Art Education in the era of University of Education, Winneba has exponentially increased but using the same lecture and studio spaces used in the days of the University College of Education of Winneba.

The Department of Art Education seriously lack both lecture and studio spaces even for lectures. This leave the authorities of the Department of Art Education with no option than to look on when students' project works are left at the mercy of the weather to destroy. Parsons the New School for Design with its prestigious reputation of a student-teacher ratio of 9:1 is considered as one of the best art schools in the world today (Format, 2018). Kanko-Arthur (2020) said "they were only eight students" in their painting class while studying for the Diploma in Art at the then University College of Education of Winneba. Kanko-Arthur further stated that the eight painting students had a whole studio to themselves. They left their aisles at the painting studio without bothering to move their work till it is assessed and they held exhibition at the end of the academic year till school reopened. Currently, five lecturers handle two hundred and eighty-four students offering Basic Drawing in their third year (Mensah, 2020). Mensah (2020) further stated that he had eighty-eight students offering Painting for the 2018/2019 academic year using the same painting studio. But nowhis students had to leave the studio after lectures for other lectures to take place in the studio. It is clearly evident thatUniversity of Education, Winneba continue to have challenges with studio spaces for the Department of Art Education to cater for the large students' intakes studying art education (UEW, 2016; UEW, 2018). Much has not been done in terms of studio space and storing away students' project works except a shed added to the existing lecture rooms and studios the Department of Art Education inherited from the Specialist Teacher Training College to the University of College of Education of Winneba in the early 1990s. Chassis of destroyed students' project works becomes nuisance and rubbish that the students' association of the department are compelled to clear this rubbish away at the beginning of every semester to make room for their lectures. This issue is observed every semester considering the total number of students the department has and the number of projects each student has to produce within a semester. Considering the number of students, the Department of Art Education hold and its related lack of infrastructure, specialized studios and rooms for specific lectures has not been able to help in this matter.

Students' are not able to leave ongoing projects at the department as the limited lecture rooms and studios are required for the use of other students. This practice has not been helpful especially with the studio projects which students take along with them whenthe theoretical aspect of the lecture is ended but the project is not done. Lecturers and technicians are not in the position to give assistance to students when project works are executed out of the studios and lecture rooms. It came to light from the interaction with the subjects (units) that lecturers have a challenge ascertaining if his or her students executed the project works by themselves. The other side of this challenge of the lecturers was with the students. Students often required the attention of their lecturers and technicians when they encounter challenges as they execute their project works out of the sight of the lectures and technicians. Due to lecture and studio spaces challenge at the Department of Art Education, students' lectures are cramped within a day.Multiples of lectures for students a day often leaves these students with lectures back-to-back throughout the week; forcingstudents to abandon uncompleted project work to join in the next lecture on a row which is often very tiring for the students. Students are forced to enterinto their next lecture with them their unfinished project works because the last lecture room has a lecture and the student has no locker to leave even his tools than to carry with him or her into the next lecture. Students' wish they could come in late in the night to continue with their project works but they are robbed of such opportunity.

Students are forced to bring in taxi cabs to collect their ongoing project works to and fro since the student cannot afford to leave their works at the studio or lecture room. Some units of the Department of Art Education had issues of storing materials for students' use because all form of lectures is held 
in the suppose specialized studios and lecture rooms which is often a nuisance for both students and the lecturers. Due to lack of studio and lecture space at the Department of Art Education, students are forced to come in early to wait for their lecture because they may not have a comfortable sitting space or working space and in the process end up conversing among themselves. Such conversations often become loud and disturb and distract ongoing lectures. Course representatives draw the students' attention but the issue persist which requires that the lecturer has to come in and this is a challenge that needs attention.

Studio and lecture spaces are too tight for the number of students at the Department of Art Education offering each course that its often impossible for students to move around in class even if one has to use the toilet. Students are not able to exhibit their project works for commentary to aid them work on their weakness to perform better in their next project. Some students do not get the opportunity to collect their project works after assessment by the lecturer when they are readily not available. They only find their project works rather destroyed. The researcher observed that students cart truckloads of project works to the refuse dump at the beginning of every semester to make room for the new semester project works. This exercise comes at a cost to the students' association because the volume of rubbish these project works generate as well as the projects works that need to be cleared away are too large for the University cleaners assigned to the department to handle.

The issue of space at the Department of Art Education is out of hand as course leaders, of the various courses, have to lay ambush for lecture rooms. The impatiently wait at the entrance of these places to capture the venue for their use. The senior members could not stash their offices with students' project works and are often forced to instantly mark and return the project works to the students or they may not have space for themselves.Senior members of the Department of Art Education lamented the situation is not healthy for teaching and learning in this 21 st century. The senior members observed this situation did not help them observe the progress of their students since every semester's project works has to be cleared to make room for the new semester's work. One could not leave best students project works in the studio and lecture rooms neither could they store such project works in their offices. It is disheartening to see project works being destroyed and some of the senior members of the Department of Art Education felt bad when they task students to execute good projects works considering the monetary aspect involved and one looks on helplessness when it has to be cart away to make room for new project works. Some large tools and machines had to be put away due to space.

It comes up among the senior members that they had no space to practice to encourage students. Some senior members are forced to practice at their residence instead. Lecturers could not task students to execute life size project works because of such project works would be destroyed to make room for other project. Senior members lamented that they are overwhelmed by the number of students the department admit every year which is a challenge for them. The only tiny art gallery of the Department of Art Education could neither hold any more works as it has been obsolete considering its size and the fact that it is a makeshift gallery. This gallery is not a purpose built one. Senior members of the Department of Art Education look forward to a befitting art gallery, studios and lecture rooms. A gallery would exhibit some good project works of students and aid teaching and learning at the department as some senior members observed. Senior members hoped they got help with the documentation and archival of students' project works in any form.

The researcher again observed that best selected project works for exhibitions are stored in the same lecture rooms and studios where students hold lectures. These best selected project works collect dust and often touched by students from other units within the Department of Art Education.These students are fascinated by these works as they use the studios and lecture rooms for their lectures eventually destroying these works.

\section{CONCLUSION AND RECOMMENDATIONS}

Students' project worksare hard to find, inappropriate for reference purposes and does not support teaching and learning purposes at the Department of Art Education. Best selected project works of students exhibited at the art gallery have collected dust and are not appropriate for exhibition so the Department of Art Education are discouraged to keep more of such works. The project works of students at the department are nuisance and is nothing less than rubbish. Due to the issue of space at the department, students' project worksare not well stored considering the haphazardly manner in which works of studentsare handled within the studios of the Department of Art Education. Students 
studying the various aspects of art should be encouraged to find solution in archiving their project works. This habit when formed early would be taken along with students from the department to teach visual art to students at the Senior High Schools.

Broken down chassis of students' sculpture works should be disposed of well as the clearing of rubbish and project works of students are often concentrated within the studios leaving works at the entrance to the department and around the buildings. Though the department has initiated the construction of sheds but it is a temporary solution to create space though it's not enough. The challenge at hand at the Department of Art Education requires a collective support from stakeholders and the University authorities. Construction of sheds within the department could temporarily ease the challenge to some extend while the Department of Art Education together with the University find a lasting solution.

Project works of students at the Department of Art Education should be collated, sorted, documented, archived and exhibited through digital archives. Digital archives would provide a solution to the myriad and variant media of art works as well as the cultural preservation produced by students year on year during their study at the Department of Art Education.Senior members at the department could employ the use of 3-D technology to cut down on the number of projects works students execute within a semester. The use of technology would be a first step in archiving to reach a wider audience and for research purposes.

The researcher recommends that the Department of Art Education contracts web designers to design a database to host still images and $360^{\circ}$ moving images of these art works to start with in solving this challenge of the department. The Department of Art Education and the University of Education, Winneba should also build a digital repository to hold documented digital versions of the project works of students to aid teaching and learning. Senior members of the Department of Art Education should write grant proposal for funding to support this cause. The researcher hopes this paper opens a discussion and further studies in this direction to aid, establish and archive visual art well within the Ghanaian culture.

\section{REFERENCES}

[1] Acquah, E. K. (2020, August 23). Lecture and studio spaces. Winneba, Effutu Municipal, Ghana.

[2] Agyemang, M., Hagan, E. \& Agyabeng, S. (2019). Technology use among Ghanaian Senior High School students' in learning mathematics and the factors that influence it. African Journal of Educational Studies in Mathematics and Sciences Vol. 15. Pp. 77-87. http://creativecommons.org /licenses/by-nc-nd/4.0. DOI: https://dx.doi.org/10.4314/ajesms.v15i1.7

[3] Artwatch Ghana. (2017). The state of Creative Arts in Ghana.2017 Artwatch Ghana Annual Report (Research Report 15042017). Ghana: Artwatch Ghana.

[4] Brobbey, D. (2015). Creative art education "A must have". Retrieve from https://www.modernghan a.com/news/659311/1/creative-art-education-a-must-have.html.

[5] Diallo, A. (2017, July 4). The teaching methods of Ghana's Kwame Nkrumah University of Science and Technology has cultivated a new generation of innovative artists. Contemporary And (C\&): Institut für Auslandsbeziehungen. C\& Print Issue \#7. https://www.contemporaryand.com/magazines/ past-presentand-future-about-art-in-kumasi/.

[6] Edusei, K. (2004). An overview of visual art education in Ghanaian schools. Journal of science and technology, Vol. 24 No. 2, pp.116-120. http://hdl.handle.net/123456789/5105.

[7] Elias, T. O. (1957). Ghana: Autobiography of Kwame Nkrumah, African affairs. Vol. 56, Issue 224. pp.238-239. https://doi.org/10.1093/oxfordjournals.afraf.a094495.

[8] Endert, J. (2018). Despite Ghana's commitment to internet expansion, problems persist. Retrieve from DW Akademie. \#Speakup barometer Ghana: https://www.dw.com/en/despite-ghanas-commitment-to-internetexpansion-problems-persist/a-46508524.

[9] Essel, H. B., Nunoo, F. K. N. \& Ahiaklo-Kuz, N. A. Y. (2017). Development of an Integrated Art and Visual Programming Framework for Ghanaian Basic Schools based on a 21st century skill deficiency diagnostic on two basic school subjects. American Research Institute for Policy Development. Vol. 6, No. 4, pp.89-98. ISSN: 2334-296X (Print), 2334-2978 (Online). DOI: 10.15640/jehd.v6n4a10. URL: https://do i.org/10.15640/jehd.v6n4a10. 
[10] Format. (2018, September 21). Art: The 34 Best Art Schools in the World. Retrieved from Format.com: https://www.format.com/magazine/resources/art/best-art-schools-world.

[11] Gyimah, J. K. (2020, October 13). Lecture and studio spaces. Takoradi, Ghana.

[12] Duku, F. K. \&Osei-Poku,P.(2012). Overview of Art Education Programme in theUniversity of Education, Winneba-Ghana. International Journal of EducationalLeadership, Volume 4, No. 4, pp70-78.

[13] I.U.B. (2019). G.W.K. Dawson: A particular history of Ghanaian modernism. Solo Exhibition at Savana Centre for Contemporary Art (SCCA). Tamale, Ghana. Retrieved: https://iubeezy.wordpress. com/texts/dawson/.

[14] Jadzińska, M. (2013). Think of culture, care for art. Preservation of contemporary heritage in modern society. Paper presented at the 16th International Multiconference: Information Society Conference, Ljubljana.https://www.researchgate.net/publication/286623189_THINK_OF_CULTURE_CARE_

FOR_ART_PRESERVATION_OF_CONTEMPORARY_HERITAGE_IN_MODERN_SOCIETY/referen ces

[15] Kanko-Arthur, E. (2020, November 21). Class size. (J. F. ESSEKU, Interviewer)

[16] Kassah, J. K. \& Kemevor, A. K. (2016). The challenges of visual arts education in Ghana's colleges of education. International Journal of Scientific Engineering and Applied Science (IJSEAS). Vol. 2(3):87-98. http://ijseas.com/volume2/v2i3/ijseas20160313.pdf

[17] Martin, L. (2014). (Retrieved 2020, September 05) 10 reasons why arts in education is so important for kids. Retrieved from http://www.learningliftoff.com/10-reasons-arts-in-education-importantkids/\#.VyYQxvmLSM9.

[18] Mensah, H. E. (2009). Visual art lessons for non-visual art teachers in senior high schools in Ejisu-Juaben District. Faculty of Fine Art, College of Art and Social Sciences - KNUST. p.16. http://129.122.16.11/ bitstream/123456789/803/1/MENSAH\%20HARRY\%20EKWAM.pdf

[19] Mensah, T. K. (2020, November 22). Class size challenges. (J.F. ESSEKU, Interviewer)

[20] Mereku, D. K. (2020, September 05). Academia. Retrieved from academia.edu: https://www.acade mia.edu/8376121/Sixty_years_of_teacher_education_in_Ghana_Successes_challenges_and_the_way_for ward.

[21] NaCCA, Ministry of Education. (2019). Creative arts curriculum for primary schools (Basic 1-3). Ghana Education Service. http://nacca.gov.gh/wp-content/uploads/2019/06/CREATIVE-ARTS-B1-B3.pdf.

[22] Noordegraaf, J., Saba, C. G., Maître, B. Le\& Hediger, V. (Eds.).(2013). Preserving and exhibiting media art: Challenges and perspectives. Amsterdam University Press. https://library.oapen.org/han dle/20.500.12657/33232.

[23] Nuno-Amarteifio, N. (2017, November 27). Features. Retrieved from GhanaWeb: https://wwwghan aweb/GhanaHomePage/features/Achimota-and-its-impact-on-the-creative-arts-604307.

[24] Ockumpah-Bortei, B. S. (2020, March 23). Lecture and studio spaces. (J. F. Esseku, Interviewer).

[25] Opoku-Mensah, I. (2020, July 03). Lecture and studio spaces. (J. F. Esseku, Interviewer)

[26] Quaynor, N., Tevie, W. \& Bulley, A. (2016). Expansion of the internet backbone in Ghana. Retrieved from ITHS: https://web.archive.org/web/20160103124842/https://www.isoc.org/inet97/proceedings/E5/ E5_2.HTM.

[27] Ross, M. (2004). Art at crossroads: The contested position of indigenous arts in Ghana's post-colonial education system. Studies in art education.A journal of Issues and Research Vol. 45(2). pp.117-134. Retrieved from https://www.jstor.org/stable/1321096?seq=1\&cid=pdf-reference\#freferences_tab_co ntents.

[28] Savage, K. (2009). Monument wars:Washington D.C., the National Mall, and the Transformation of the Memorial Landscape. Berkeley: University of California Press.

[29] Sei'dou, K. (2015). J. C. Okyere's bequest of concrete statuary in the KNUST collection: Special emphasis on lonely woman. Global Journal of Interdisciplinary Social Sciences. G.J.I.S.S., Vol.4(1):15-26. ISSN:2319-8834. https://www.gifre.org.

[30] Seid'ou, K. (2020). Changing Lessons: The Kumasi School of “Art and Crafts" in a Scottish Regime (1952-1962). Asian Research Journal of Arts \& Social Sciences. 11(1): 42-71, 2020; Article no. ARJASS.58116. ISSN: 2456-4761.

[31] Stanley, J. L. (2020, March). Modern African art: a basic reading list. Smithsonian Libraries.https://www.sil.si.edu/SILPublications/ModernAfricanArt/newmaa.cfm.

[32] UEW. (2016). University of Education, Winneba Corporate Strategic Plan. 2014-2018. UEW Printing Press.

[33] UEW. (2018). Consolidated Annual Estimates and Operating Budget for 2016. UEW Printing Press. 
[34] University of Education, Winneba. (2018). 22nd Congregation. 2nd Session, Basic Statistics. Winneba: Publishing and Web Design.

\section{AUTHOR'S BIOGRAPHY}

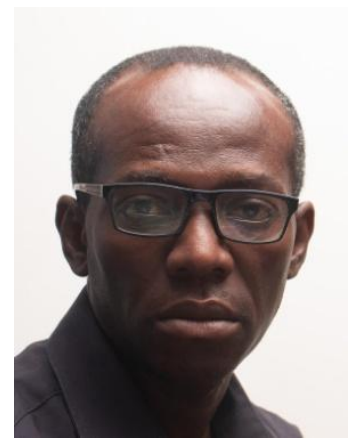

Esseku, J. F, Originally trained as a professional teacher in 1992 and has been in teaching since. Currently teach Computer Generated Graphic Design courses at the Department of Graphic Design at the University of Education, Winneba-Ghana though trained at the Department of Art Education of the same university. Author holds a PhD in Arts \& Culture; specialising in Technology and Art and a Lecturer in Graphic Design. Author has taught Graphic Design courses at the University level for over 10years. Author has been involved in the production of Distance Education Study Materials. Author doubles as a professional graphic artist and freelance graphic designer. Author's interest in technology has seen him undertake Art and Technology researches.

Citation: Esseku, J. F. "The State of Art Education Students' Project Works: the Case of UEW" International Journal of Humanities Social Sciences and Education (IJHSSE), vol 7, no. 12, 2020, pp. 15-23. doi: https://doi.org/10.20431/2349-0381.0712002.

Copyright: (c) 2020 Authors. This is an open-access article distributed under the terms of the Creative Commons Attribution License, which permits unrestricted use, distribution, and reproduction in any medium, provided the original author and source are credited. 